\title{
Combined effect of hot water dipping and Cistus creticus L. leaf extracts on the storage quality of fresh Valencia oranges
}

\author{
İbrahim Kahramanoğlu ${ }^{1}$, Serhat Usanmaz, ${ }^{1}$ Turgut Alas $^{1}$, \\ Volkan Okatan', Chunpeng Wan ${ }^{3, *}$

\begin{abstract}
${ }^{1}$ Department of Horticultural Production and Marketing, Faculty of Agricultural Sciences and Technologies, European University of Lefke, Gemikonağı, Northern Cyprus TR-10 Mersin, Turkey

${ }^{2}$ Department of Horticulture, Faculty of Agriculture and Natural Sciences, Uşak University, Uşak, Turkey ${ }^{3}$ Jiangxi Key Laboratory for Postharvest Technology and Nondestructive Testing of Fruits \& Vegetables, Collaborative Innovation Center of Postharvest Key Technology and Quality Safety of Fruits \& Vegetables in Jiangxi Province, College of Agronomy, Jiangxi Agricultural University, Nanchang 330045, China
\end{abstract}

\begin{abstract}
This research was designed to test the combined efficacy of hot water dipping (HWD) and leaf extracts of Cistus creticus L. subsp. creticus on the storage quality of fresh Valencia oranges. Experiments were laid down according to a completely randomised design with 10 different treatments. Five replications, with five fruits in each replication, were used in the current study, and research was designed to continue for 150 days. Quality characteristics were observed with 30-days interval. The applications of this study were (1) Control [dipping in water at $25^{\circ} \mathrm{C}$ for $5 \mathrm{~min}$ ]; (2) $\mathrm{HWD}$ at $50^{\circ} \mathrm{C}$ for $5 \mathrm{~min}$; (3) HWD + Additives (A) [Arabic gum (0.2\%), potassium sorbate $(0.05 \%)$, citric acid $(0.05 \%)$ and vitamin C $(0.05 \%)$ ] at $50^{\circ} \mathrm{C}$ for $5 \mathrm{~min}$; (4) Additives alone at $25^{\circ} \mathrm{C}$ for $5 \mathrm{~min}$; (5) $1.0 \%$ C. creticus leaf $+\mathrm{HWD}+\mathrm{A}$; (6) $1.0 \%$ C. creticus leaf $+\mathrm{A}$; (7) $0.5 \%$ C. creticus leaf + HWD + A; (8) $0.5 \%$ C. creticus leaf + A; (9) $0.5 \%$ C. creticus leaf + HWD and (10) $0.5 \%$ C. creticus leaf. According to the results obtained, both the HWD and C. creticus, alone or in combination, were effective in preserving orange weight during storage, preventing pathogenic decay, maintaining visual quality and fruit firmness, delaying the reduction in titratable acidity, increasing ascorbic acid content and reducing respiration rate of the orange fruits. Results also suggested that the combined effect of HWD with C. creticus leaf extracts provided the highest efficacy.
\end{abstract}

Keywords: combined effect, hot treatment, pathogen control, plant extracts, postharvest storability

\section{INTRODUCTION}

Citrus fruits have been the most produced fruits products on the earth until today, with 138,550,381 tonnes of production in 2018. The percentage of oranges, mandarins (including tangerines, clementines and satsumas), lemons (including limes) and grapefruits (including pomelos) are 54.4\%, 24.8\%, 14.0\% and $6.8 \%$, respectively. The top three countries for orange production are Brazil, China and India, which cover about $45.5 \%$ of total orange production (FAO, 2020) in total. Besides the fresh consumption, citrus fruits are also consumed as juice. They have been highly consumed throughout the world, while they have a unique flavour and are rich in minerals, phytochemicals and dietary fibre (Farag et al., 2020). Valencia oranges (Citrus sinensis L. Osbeck), with several bioactive compounds and rich nutritional contents, are among the most consumed citrus species (Albertini et al., 2006). A glass of orange juice $(225 \mathrm{ml})$ was reported to contain about $1,225 \mathrm{mg}$ of vitamin C (AsA, ascorbic acid), $5 \mathrm{mg}$ of folic acid and $500 \mathrm{mg}$ of potassium (Whitney and Rolfes, 1999). It is

*Corresponding author.

e-mail: chunpengwan@jxau.edu.cn (Chunpeng Wan). 
also well known that the pomological and biochemical characteristics of fruit crops significantly change among genotypes, growing conditions and cultural practices (Okatan et al., 2018; Çolak and Özoğul, 2020). However, the postharvest storability of Valencia oranges is limited to about 3 months and was noted to highly influence by pathogenic decay and weight loss (Alhassan et al., 2020). Most important pathogens causing postharvest decay are Penicillium digitatum and Penicillium italicum and storing the oranges at low temperatures is among the effective ways for controlling those pathogens. However, prolonged storage at low temperatures $\left(<5-8^{\circ} \mathrm{C}\right)$ induces the reactive oxygen species (ROS) production and damage the cell wall of orange fruits, which reduce the postharvest storability of oranges (Lado et al., 2016; Wan et al., 2020).

Control of postharvest pathogens of orange fruits generally relies on the application of agrochemicals (Sharma et al., 2009). However, the acceptability of agrochemicals by the consumers has been decreasing due to scientific confirmation (Hussien et al., 2018) of their adverse effects on human health when they are misused or used in excessive amounts (Koch et al., 2017). Search for alternatives to the synthetic agrochemicals resulted in high success with different biomaterials, which have extended threshold for toxicity (Silvestre et al., 2011; Tomazoni et al., 2016). Coating of fruits with edible biomaterials provides a semipermeable barrier for atmospheric gaseous and water vapour and reduces respiration and transpiration, which in turn prolongs the storability of fruits (Kahramanoğlu 2017; Riva et al., 2020). Biomaterial coating also helps to control pathogens with direct inhibition of pathogens or by indirect improvement of fruits' resistance (Ncama et al., 2019). Postharvest application of biomaterials (edible coatings and films, essential oils, jasmonic acid, plant-derived products, etc.) has been suggested by several studies to improve the storability of horticultural products (Hassanein et al., 2018; Ncama et al., 2019; Chen et al., 2019; Kahramanoğlu 2019; Troyo and Acedo, 2019; Xin et al., 2019; Zudaire et al., 2019; Riva et al., 2020; Elkhetabi et al., 2020; Poveda, 2020) and orange fruits (Palou et al., 2015; Chen et al., 2019; Moraes Bazioli et al., 2019; Moosa et al., 2019). Different works demonstrated the antifungal activity of different plant extracts against fungal pathogens of citrus fruit (Tayel et al., 2016; Karchoufi et al., 2018; Pinto et al., 2021). Filipiak and Weiner (2017) showed the capacity of these extracts to attract or repel insects. Recent studies also showed that the terpenoids of plant essential oils, i.e. citronellal, have a significant influence on the mycelial growth and spores' germination of $P$. digitatum (Wu et al., 2016). Most of the essential oil compounds are generally recognised as safe (GRAS) and they can be used in active packaging or edible coatings.

Search for new biomaterials from different plants has been the subject of current scientific studies. Cistus creticus $\mathrm{L}$. is a widespread shrub plant found in the
Pinus sylvestris forests in the Mediterranean basin (Altay, 2019). Different sub-species of C. creticus genus, i.e. subsp. eriocephalus and corsicus, were previously noted to have diverse chemical composition. A total of approximately 164 compounds were identified from these two sub-species, and the most abundant compounds were terpenes noted as follows: $\delta$-cadinene, $\beta$-caryophyllene, $\tau$-muurolol, $\alpha$-cadinol, manoyl oxide, 13-epi-manoyl oxide and manool (Paolini et al., 2009; Abu-Orabi et al., 2020; Lahcen et al., 2020). Essential oils of C. creticus plants were previously noted to have possible medical applications, i.e. against blood cancer (Dimas et al., 1999). Volatile profiles of Cistus genus have also been reported to have antimicrobial characteristics, which makes it useful for the industrial production of cosmeceuticals (Morales-Soto et al., 2015). Limited studies exist about the fungicidal activity of Cistus extracts (Jemia et al., 2013; Karim et al., 2017). In one of these studies, Karim et al. (2017) reported that the aqueous extracts of Cistus species provide significant efficacy for controlling Citrus sour rot. However, these studies were carried out in in vitro conditions.

Moreover, postharvest pre-conditioning of fruits with hot water dipping (HWD) or any other means of heat treatment has been reported to activate/deactivate PPO (polyphenoloxidase), POD (peroxidise) and/or SOD (superoxide dismutase) enzymes and positively affects the storability of fruits (Yun et al., 2013; Opio et al., 2017; Atrash et al., 2018; Kahramanoğlu et al., 2020a; Wan et al., 2020). In recent research, Wei et al. (2018) reported that the efficacy of heat treatment on the postharvest characteristics and storability of strawberry fruits could be increased with its combination of tea tree oil. However, there has not been any study about the combined efficacy of HWD with any biomaterials. In line with this knowledge, the present study was designed to test the combined efficacy of HWD and C. creticus leaf extracts on the postharvest storability and biochemical characteristics of fresh Valencia oranges (C. sinensis L. Osbeck).

\section{MATERIALS AND METHODS}

\section{Experimental research}

Valencia oranges originally bred in southern California but were named after the city of Valencia in Spain. They are medium-sized oranges with a bright orange colour and finely textured rinds. They are very juicy with a sweet-tart flavour. Valencia oranges of the current research were purchased on-tree from a local grower located in Northern Cyprus and hand-collected by the researchers at the commercial maturity. Harvesting was performed when the fruits reached above $12 \%$ soluble solids concentration (SSC) and $<3.0 \mathrm{~g} \cdot 100 \mathrm{~g} \mathrm{~g}^{-1}$ citric acid. Valencia oranges were quickly transferred to the laboratory and hand-selected to provide uniform size and colour and to eliminate damaged and diseased fruits. Leaves of $C$. creticus L. subsp. creticus were then collected from Yeşilırmak village of Northern Cyprus. 
The fruits of the current research were first separated into 10 groups with 125 fruits in each group. These groups represent the 10 treatments of current studies. Then, the 125 fruits were separated into 25 sub-groups with 5 fruits in each group. After the application of the postharvest treatments, each group was separately stored in cold rooms at $6.0 \pm 1.0^{\circ} \mathrm{C}$ and $90-95 \% \mathrm{RH}$ (relative humidity); and five sub-groups (totally 25 fruits) from each group (treatment) were removed from the cold rooms with 30-days interval for the measurement of quality parameters. The treatments of current study were as follows: (1) control [dipping in water at $25^{\circ} \mathrm{C}$ for $5 \mathrm{~min}$;]; (2) $\mathrm{HWD}$ at $50^{\circ} \mathrm{C}$ for $5 \mathrm{~min}$; (3) HWD + Additives (A) [Arabic gum (0.2\%), potassium sorbate $(0.05 \%)$, citric acid $(0.05 \%)$ and vitamin $\mathrm{C}(0.05 \%)$ ] at $50^{\circ} \mathrm{C}$ for $5 \mathrm{~min}$; (4) Additives alone at $25^{\circ} \mathrm{C}$ for $5 \mathrm{~min}$; (5) $1.0 \%$ C. creticus leaf + HWD + A; (6) $1.0 \%$ C. creticus leaf + A; (7) $0.5 \%$ C. creticus leaf + HWD + A; (8) $0.5 \%$ C. creticus leaf $+\mathrm{A}$; (9) $0.5 \%$ C. creticus leaf + HWD; and (10) $0.5 \%$ C. creticus leaf. Detailed explanations of the treatments are given in Table 1.

\section{Data collection}

Eight different quality parameters were regularly measured with 30-days interval during the 150 days of storage. Both the initial and final weights of each fruit were measured with an electronic scale $( \pm 0.01 \mathrm{~g})$, and the values were used to calculate the weight loss in percentage (\%) by following the standard ratio analysis. Then, the method of Fonseca et al. (2002) was used to measure the respiration rate (RR) of each replication (five fruits together) as the produced $\mathrm{CO}_{2}$ $\left(\mathrm{ml} \mathrm{CO}{ }_{2} \cdot \mathrm{kg}^{-1} \cdot \mathrm{h}^{-1}\right)$. The standard method of Cao et al. (2011) was used to calculate decay incidence (DI) as a percentage by following the $0-3$ scale and standard formula. The $0-5$ scale of Silva et al. (2015) was then used to observe and score the visual quality of each fruit ( 0 : worst, 5 : best). The visual quality parameters included the observations about both browning and microbial decay.

A hand penetrometer with a probe diameter of $5 \mathrm{~mm}$ was used to assess the firmness $\left(\mathrm{kg} \cdot \mathrm{cm}^{-2}\right)$ of orange fruits. The fruits were then half-cut and squeezed to obtain clear juice for further measurements. A hand refractometer was used to assess the fruit's SSC as $\%$ and the standard titration method with $\mathrm{NaOH}$ was followed for the determination of titratable acidity (TA $-\mathrm{g} \cdot 100 \mathrm{~g}^{-1}$ citric acid). Finally, the titrating with 2,6-dichlorophenol indophenols was followed for the

Table 1. Detailed explanations of the 10 experimental treatments

\begin{tabular}{|c|c|}
\hline Treatment name & Short name - description \\
\hline Control & Control - Valencia oranges of this group were dipped into water $\left(25^{\circ} \mathrm{C}\right)$ for $5 \mathrm{~min}$ \\
\hline HWD & $\mathrm{HWD}$ at $50^{\circ} \mathrm{C}$ for $5 \mathrm{~min}-$ Fruits of this group were dipped into hot water at $50^{\circ} \mathrm{C}$ for $5 \mathrm{~min}$. \\
\hline $\mathrm{HWD}+\mathrm{A}$ & $\begin{array}{l}\mathrm{HWD}+\text { Additives }(\mathrm{A})-\text { First, water was heated until } 100^{\circ} \mathrm{C} \text {, then } 2: 1,000(\mathrm{w} / \mathrm{v}) \text { Arabic gum was } \\
\text { added and cooled down to } 50^{\circ} \mathrm{C} \text {. Next, } 0.5: 1,000(\mathrm{w} / \mathrm{v}) \text { citric acid, } 0.5: 1,000(\mathrm{w} / \mathrm{v}) \text { potassium sorbate } \\
\text { and } 0.5: 1,000(\mathrm{w} / \mathrm{v}) \text { vitamin } \mathrm{C} \text { were added and cooled down to } 50^{\circ} \mathrm{C} \text {. Finally, the fruits were } \\
\text { immersed in this solution for } 5 \text { min at a constant temperature of } 50^{\circ} \mathrm{C} \text {. }\end{array}$ \\
\hline Additives (A) & $\begin{array}{l}\text { Additives alone at } 25^{\circ} \mathrm{C} \text { for } 5 \mathrm{~min}-\text { This treatment is the same as above described HWD }+\mathrm{A} \\
\text { treatment; however, the temperature of the solution was cooled down to } 25^{\circ} \mathrm{C} \text { and fruits were } \\
\text { immersed in this solution for } 5 \mathrm{~min} \text {. }\end{array}$ \\
\hline $\mathrm{HWD}+\mathrm{CC}(1 \%)+\mathrm{A}$ & $\begin{array}{l}1.0 \% \text { C. creticus leaf }+\mathrm{HWD}+\mathrm{A}-\text { Leaves of } C \text {. creticus and water in a ratio of } 10: 1,000(\mathrm{w} / \mathrm{v}) \\
\text { were first heated until } 100^{\circ} \mathrm{C} \text {, kept hot at } 100^{\circ} \mathrm{C} \text { for } 30 \mathrm{~min} \text { and filtered, then } 2: 1,000(\mathrm{w} / \mathrm{v}) \text { Arabic } \\
\text { gum was added and cooled down to } 50^{\circ} \mathrm{C} \text {. Next, } 0.5: 1,000(\mathrm{w} / \mathrm{v}) \text { citric acid, } 0.5: 1,000(\mathrm{w} / \mathrm{v}) \\
\text { potassium sorbate and } 0.5: 1,000(\mathrm{w} / \mathrm{v}) \text { vitamin } \mathrm{C} \text { were added. Finally, the fruits were immersed in } \\
\text { this solution for } 5 \mathrm{~min} \text { at } 50^{\circ} \mathrm{C} \text {. } \\
\text { Steam distillation is a widely used method for obtaining the volatile fraction of } \text { Cistus spp. } \\
\text { (Oller-López et al., 2005). }\end{array}$ \\
\hline $\mathrm{CC}(1 \%)+\mathrm{A}$ & $\begin{array}{l}1.0 \% \text { C. creticus leaf }+\mathrm{A}-\text { Preparation of this treatment is similar to the } \mathrm{HWD}+\mathrm{CC}(1 \%)+\mathrm{A} \text {, } \\
\text { where the only difference is the solution temperature. In this treatment, the solution was cooled } \\
\text { down to } 25^{\circ} \mathrm{C} \text {, and fruits were immersed in this solution for } 5 \text { min at } 25^{\circ} \mathrm{C} \text { instead of } 50^{\circ} \mathrm{C} \text {. }\end{array}$ \\
\hline $\mathrm{HWD}+\mathrm{CC}(0.5 \%)+\mathrm{A}$ & $\begin{array}{l}0.5 \% \text { C. creticus leaf + HWD - This treatment is similar to the HWD + CC }(1 \%)+\text { A treatment, } \\
\text { where the concentration of the } C . \text { creticus leaves was the half of it, as } 5: 1,000(\mathrm{w} / \mathrm{v}) .\end{array}$ \\
\hline $\mathrm{CC}(0.5 \%)+\mathrm{A}$ & $\begin{array}{l}0.5 \% \text { C. creticus leaf }+\mathrm{A}-\text { This treatment is similar to the } \mathrm{CC}(1 \%)+\text { A treatment, where the } \\
\text { concentration of the } C \text {. creticus leaves was the half of it, as } 5: 1,000(\mathrm{w} / \mathrm{v}) .\end{array}$ \\
\hline $\mathrm{HWD}+\mathrm{CC}(0.5 \%)$ & $\begin{array}{l}0.5 \% \text { C. creticus leaf }+\mathrm{HWD}-\text { Leaves of } C \text {. creticus and water in a ratio of } 5: 1,000(\mathrm{w} / \mathrm{v}) \text { were } \\
\text { first heated until } 100^{\circ} \mathrm{C} \text {, kept hot at } 100^{\circ} \mathrm{C} \text { for } 30 \mathrm{~min} \text { and filtered, and then cooled down to } 50^{\circ} \mathrm{C} \text {. } \\
\text { Finally, the fruits were immersed in this solution for } 5 \mathrm{~min} \text { at } 50^{\circ} \mathrm{C} \text {. }\end{array}$ \\
\hline $\mathrm{CC}(0.5 \%)$ & $\begin{array}{l}0.5 \% \text { C. creticus leaf - Leaves of } C \text {. creticus and water in a ratio of } 5: 1,000(\mathrm{w} / \mathrm{v}) \text { were first heated } \\
\text { until } 100^{\circ} \mathrm{C} \text {, kept hot at } 100^{\circ} \mathrm{C} \text { for } 30 \mathrm{~min} \text { and filtered, and then cooled down to } 25^{\circ} \mathrm{C} \text {. Finally, the } \\
\text { fruits were immersed in this solution for } 5 \mathrm{~min} \text { at } 25^{\circ} \mathrm{C} \text {. }\end{array}$ \\
\hline
\end{tabular}

CC, C. creticus; HWD, hot water dipping. 
assessment of AsA contents as $\mathrm{mg} \cdot 100 \mathrm{~g}^{-1}$ (Youssef and Hussien, 2020).

\section{Statistical analysis}

Raw data of each treatment at each measurement point were summarised in Microsoft Excel, and line figures were prepared with the means and standard deviations of the data. Hereafter, the raw data were analysed in SPSS 22.0 software to compare treatments with oneway analysis of variance (ANOVA), and the statistical separation of means from each other was then performed with Tukey's HSD test $(p<0.05)$.

\section{RESULTS}

\section{Influence of C. creticus leaf extracts and HWD on weight loss}

The findings of the present study showed that, as usual, weight loss of the Valencia oranges increases during cold storage (Table 2).

Furthermore, findings showed that the highest weight loss was observed from the control treatment; and all other test applications are effective in preventing weight loss (Figure 1). Among the test treatments, Additives (A) alone had the least effect and no significant difference was noted among the control and Additives. At the first measurement point (30 days after cold storage), the highest weight loss was observed from the control treatment with 5.38\% and the lowest weight loss was found to be $2.99 \%$ from the HWD + CC $(0.5 \%)$ treatment. The same trend was continued till the end of the storage period, but the difference between the HWD + CC $(0.5 \%)$ treatment and the others decreased. Thus, at the 150th day of storage, no significant difference was found among the HWD and C. creticus leaf extracts treatments and any of their combinations. Although no significant difference was noted for those of the test treatments, the best treatment in terms of the prevention of the weight loss was found to be HWD + CC $(0.5 \%)$ treatment.

\section{Influence of $C$. creticus leaf extracts and HWD on fruit firmness}

The general efficacy of the tested treatments on the firmness of orange fruits was found to be in conjunction with the efficacy of weight loss. However, some of the treatments were found to have lower efficacy on firmness than weight loss prevention. These treatments are the HWD, HWD + A and Additive (Figure 2). The firmness of orange fruits decreased during the storage, and at the end of the 150 days of cold storage, the lowest fruit firmness was noted from these four treatments (control, HWD, HWD + A and Additive), which varied from 0.54 to $0.57 \mathrm{~kg} \cdot \mathrm{cm}^{-2}$. Furthermore, no significant difference was noted among the other six treatments (HWD + CC $(1 \%)+\mathrm{A}, \mathrm{CC}(1 \%)+\mathrm{A}, \mathrm{HWD}+\mathrm{CC}(0.5 \%)+\mathrm{A}, \mathrm{CC}$ $(0.5 \%)+\mathrm{A}, \mathrm{HWD}+\mathrm{CC}(0.5 \%)$ and $\mathrm{CC}(0.5 \%))$. The fruit firmness of these treatments was found to vary from 0.65 to $0.69 \mathrm{~kg} \cdot \mathrm{cm}^{-2}$. Results showed that treatments with $C$. creticus leaf extracts have higher efficacy than the other treatments. Thus, current findings reveal that the efficacy of the treatments on fruit firmness is due to the $C$. creticus leaf extracts.

\section{Influence of $C$. creticus leaf extracts and HWD on visual quality}

Visual quality is an important parameter for the marketability of fresh horticultural products and is known to decrease during storage. As expected, the visual quality of the Valencia oranges showed a decreasing trend during the 150 days of cold storage (Table 2). In the beginning of the experiments, the fruits were all selected to have the best quality for each group of treatments (Figure 3). Thus, the initial quality of all treatments was 5.00. The visual quality of the control fruits showed the highest reduction during the first 30 days of storage and the visual quality score was decreased to 3.20. At the same time, the visual quality score of the fruits treated with Additives and CC $(1 \%)+$ A was noted as 4.40 . Similar to the fruit firmness, results suggested that the HWD treatment

Table 2. Influence of storage duration (days) on the means of observed quality parameters of Valencia oranges

\begin{tabular}{lrrrrrc}
\hline Quality parameters & \multicolumn{7}{c}{ Time } \\
\cline { 2 - 7 } & Day 0 & Day 30 & Day 60 & Day 90 & Day 120 & Day 150 \\
\hline Weight loss (\%) & $0.00 \mathrm{f}$ & $4.50 \mathrm{e}$ & $6.42 \mathrm{~d}$ & $8.46 \mathrm{c}$ & $10.84 \mathrm{~b}$ & $11.92 \mathrm{a}$ \\
Firmness $\left(\mathrm{kg} \cdot \mathrm{cm}^{-2}\right)$ & $0.72 \mathrm{a}$ & $0.67 \mathrm{~b}$ & $0.67 \mathrm{~b}$ & $0.64 \mathrm{bc}$ & $0.63 \mathrm{c}$ & $0.62 \mathrm{c}$ \\
Decay incidence $(\%)$ & $0.00 \mathrm{e}$ & $2.93 \mathrm{de}$ & $5.87 \mathrm{~cd}$ & $10.45 \mathrm{bc}$ & $13.93 \mathrm{ab}$ & $17.87 \mathrm{a}$ \\
Visual quality $(1-5)$ & $5.00 \mathrm{a}$ & $3.94 \mathrm{~b}$ & $3.90 \mathrm{bc}$ & $3.58 \mathrm{~cd}$ & $3.28 \mathrm{~d}$ & $2.80 \mathrm{e}$ \\
Soluble solid content $(\%)$ & $12.08 \mathrm{~d}$ & $12.33 \mathrm{c}$ & $12.45 \mathrm{bc}$ & $12.85 \mathrm{a}$ & $12.65 \mathrm{ab}$ & $12.53 \mathrm{bc}$ \\
Titratable acidity $\left(\mathrm{g} \cdot 100 \mathrm{~g}^{-1}\right)$ & $2.75 \mathrm{a}$ & $2.63 \mathrm{~b}$ & $2.46 \mathrm{c}$ & $2.05 \mathrm{~d}$ & $1.71 \mathrm{e}$ & $1.52 \mathrm{f}$ \\
Ascorbic acid $\left(\mathrm{mg} \cdot 100 \mathrm{~g}^{-1}\right)$ & $37.30 \mathrm{e}$ & $54.00 \mathrm{~d}$ & $63.68 \mathrm{ab}$ & $66.38 \mathrm{a}$ & $62.05 \mathrm{~b}$ & $58.27 \mathrm{c}$ \\
Respiration rate $\left(\mathrm{ml} \mathrm{CO}_{2} \cdot \mathrm{kg}^{-1} \cdot \mathrm{h}^{-1}\right)$ & $23.29 \mathrm{a}$ & $12.34 \mathrm{c}$ & $6.24 \mathrm{de}$ & $4.82 \mathrm{e}$ & $7.26 \mathrm{~d}$ & $14.35 \mathrm{~b}$ \\
\hline
\end{tabular}

Means of quality characteristics at the different storage time were compared with Tukey's HSD test $(p \leq 0.05)$ where means with different letters differ significantly $(p \leq 0.05)$. 


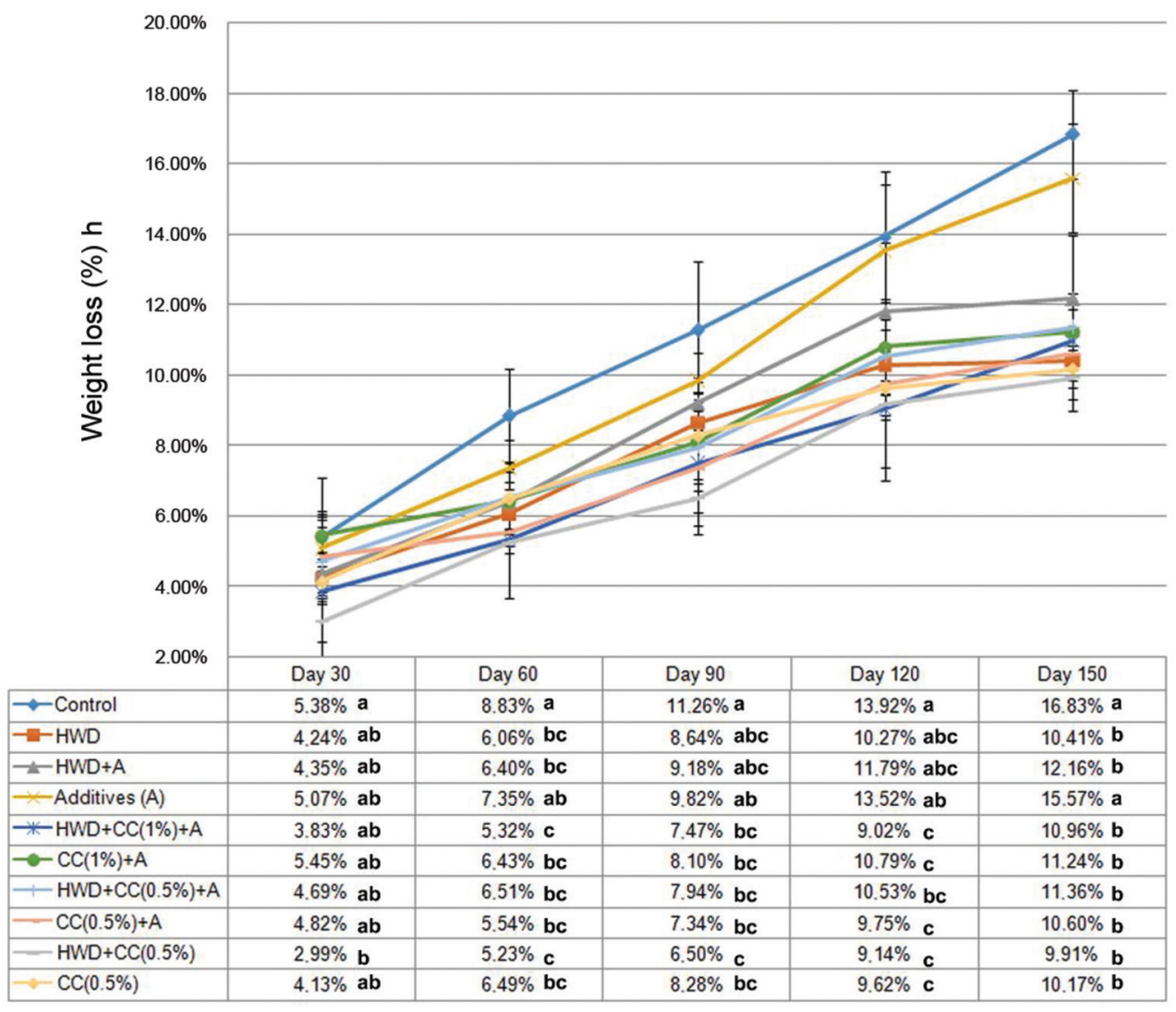

Figure 1. Effects of C. creticus leaf extracts, hot water dipping and their combination on the weight loss of Valencia oranges. Means of different treatments at the same storage time were compared with Tukey's HSD test $(p \leq 0.05)$ where means with the same letter or letters are statistically similar.

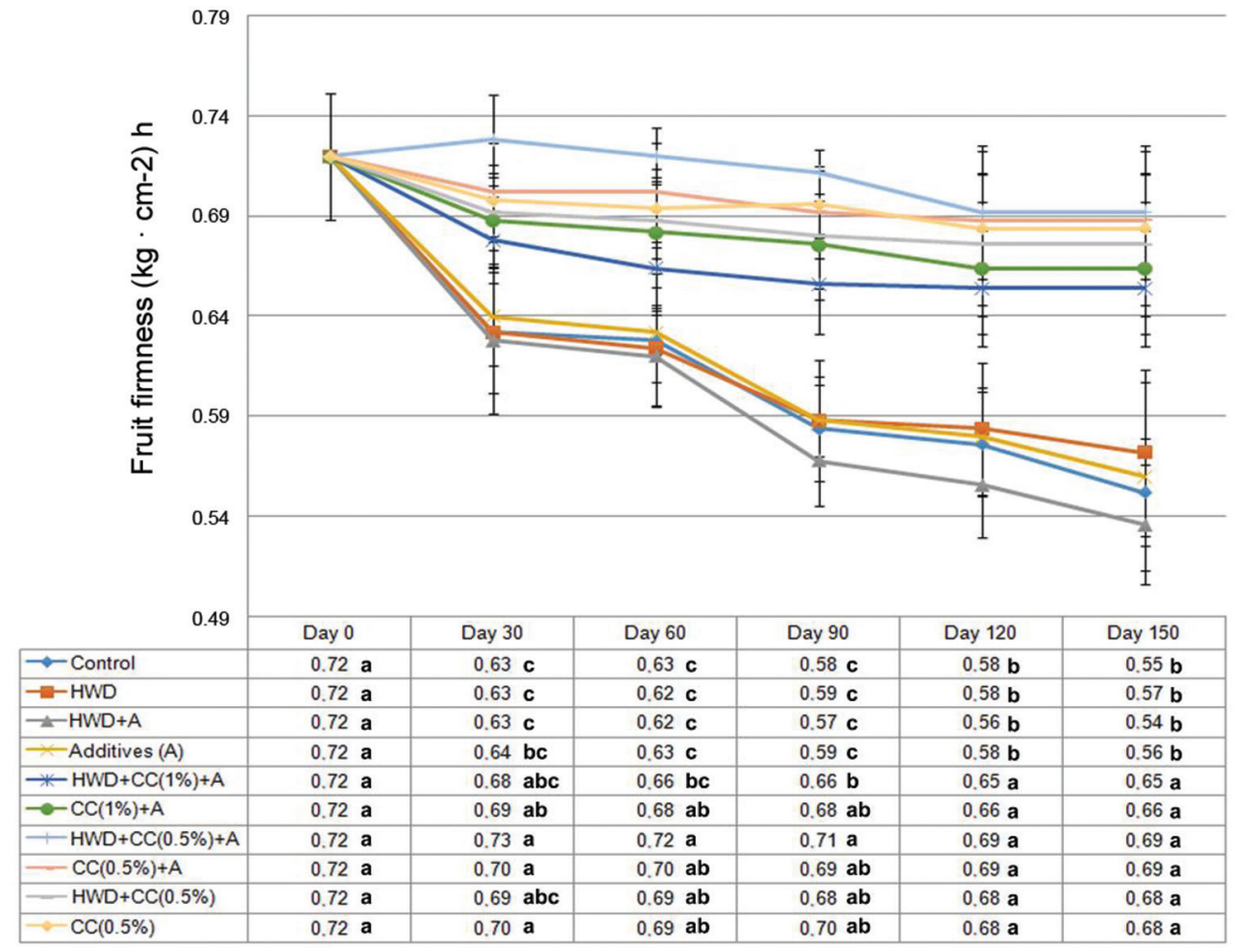

Figure 2. Effects of C. creticus leaf extracts, hot water dipping and their combination on the fruit firmness of Valencia oranges. Means of different treatments at the same storage time were compared with Tukey's HSD test $(p \leq 0.05)$ where means with the same letter or letters are statistically similar. 


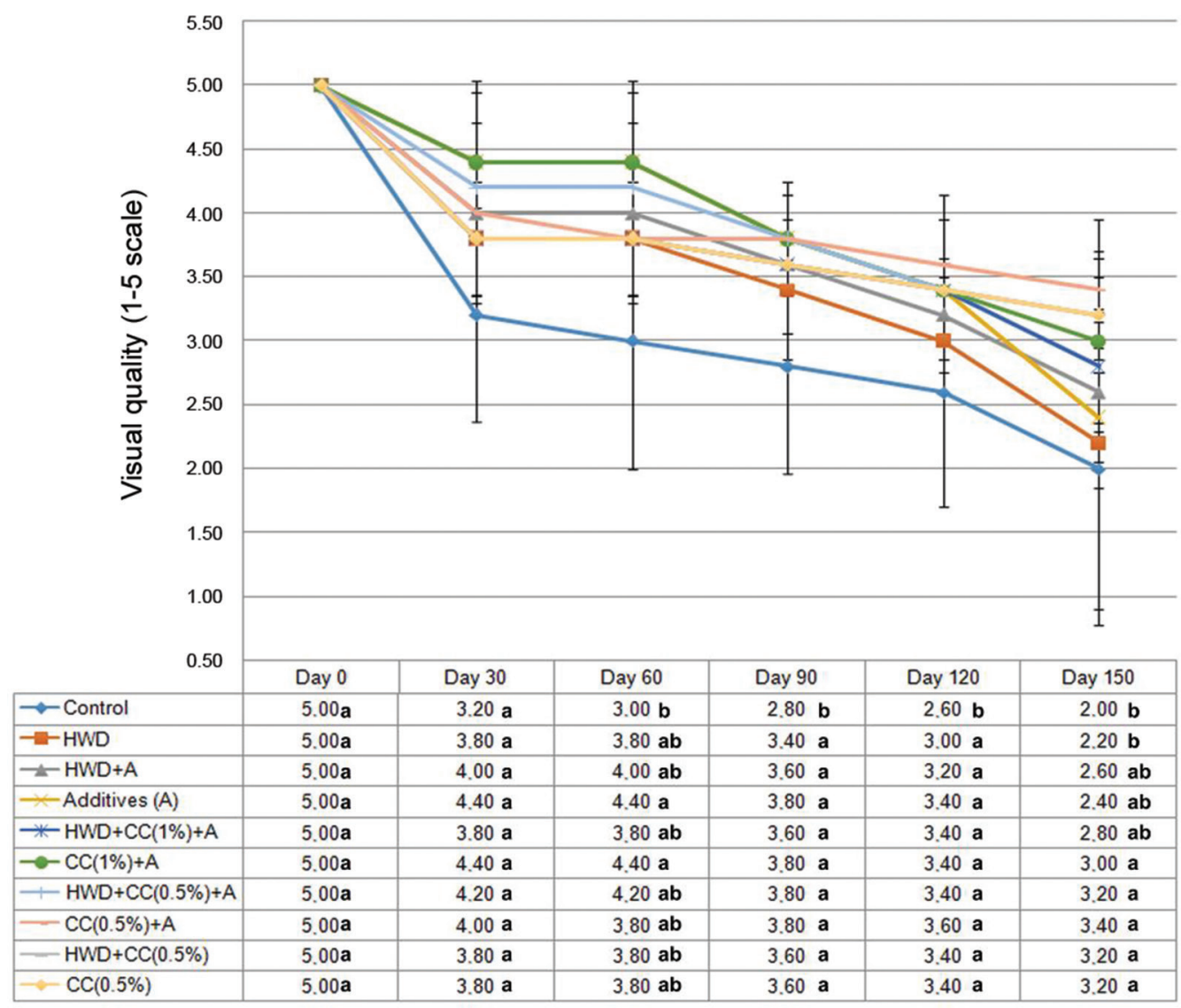

Figure 3. Effects of C. creticus leaf extracts, hot water dipping and their combination on the visual quality of Valencia oranges. Means of different treatments at the same storage time were compared with Tukey's HSD test $(p \leq 0.05)$ where means with the same letter or letters are statistically similar.

alone is not so effective in the prevention of the loss in visual quality. Moreover, the combination of HWD with Additives and/or C. creticus leaf extracts was noted to have a high influence on the prevention of quality loss. A similar trend was found to continue till the end of the experiments, and at the end of the studies, the highest visual quality score was noted from the $\mathrm{CC}(0.5 \%)+\mathrm{A}$ treatment with a score of 3.40. This was found to be above the acceptable marketability quality score of 3.00. The visual quality score of the control fruits was recorded as 2.00 and was followed by the HWD treatment with a score of 2.20 .

\section{Influence of $C$. creticus leaf extracts and $H W D$ on DI}

Pathogenic decay is so important for the protection of postharvest storability of fresh horticultural products. Elimination of the decay improves the storability and the acceptability of the products by the consumers. The present study resulted in meaningful findings for the elimination of the DI. It was noted that all test applications, even the Additives alone, are effective in the prevention of the DI. The increasing trend of the DI can be followed from Table 2 and/or Figure 4. DI of control fruits increased from $13.33 \%$ at day 30 to $48.00 \%$ at day 150 (Figure 4). It is clear from the results that about half of the fruits were lost during the 150 days of storage if they were not treated with any of the treatments. The second highest fruit loss (caused by DI) was noted from the Additives treatment as $22.67 \%$ and followed by CC $(0.5 \%)$ with a DI of $18.67 \%$. The findings of the present study revealed that the HWD application is effective in the prevention of the DI and the lowest DI score of 9.33\% was noted from the combination of HWD with CC $(1.0 \%)$ and Additives. However, no significant difference was noted with the other treatments, showing significant differences only with the control fruit.

\section{Influence of $C$. creticus leaf extracts and HWD on SSC}

Fruit SSC is an important internal quality characteristic for the consumers, which together with TA determines the fruit flavour. Present findings showed that the SSC content of the fruits had an upward tendency during the first 90 days of storage and then had a decreasing trend. The initial SSC of Valencia oranges was recorded as $12.08 \%$ and increased to $12.85 \%$ in 90 days of storage. The final SSC content of the mean of all treatments was $12.53 \%$ on the 150 th day of cold storage (Table 2). On the other hand, the treatments were noted to have no significant influence on the fruit SSC. At the end of the 150 days of cold storage, 


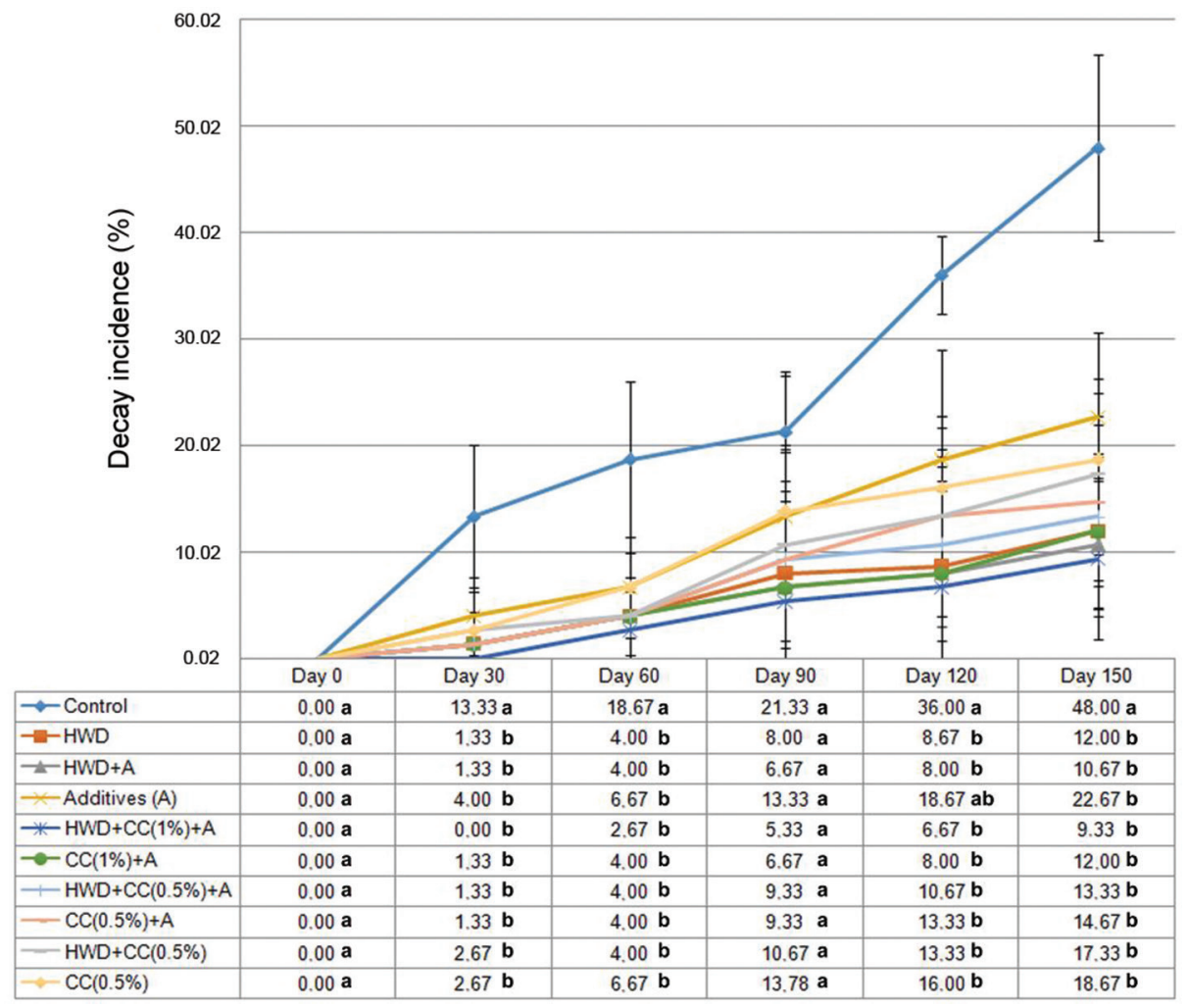

Figure 4. Effects of $C$. creticus leaf extracts, hot water dipping and their combination on the decay incidence of Valencia oranges. Means of different treatments at the same storage time were compared with Tukey's HSD test $(p \leq 0.05)$ where means with the same letter or letters are statistically similar.

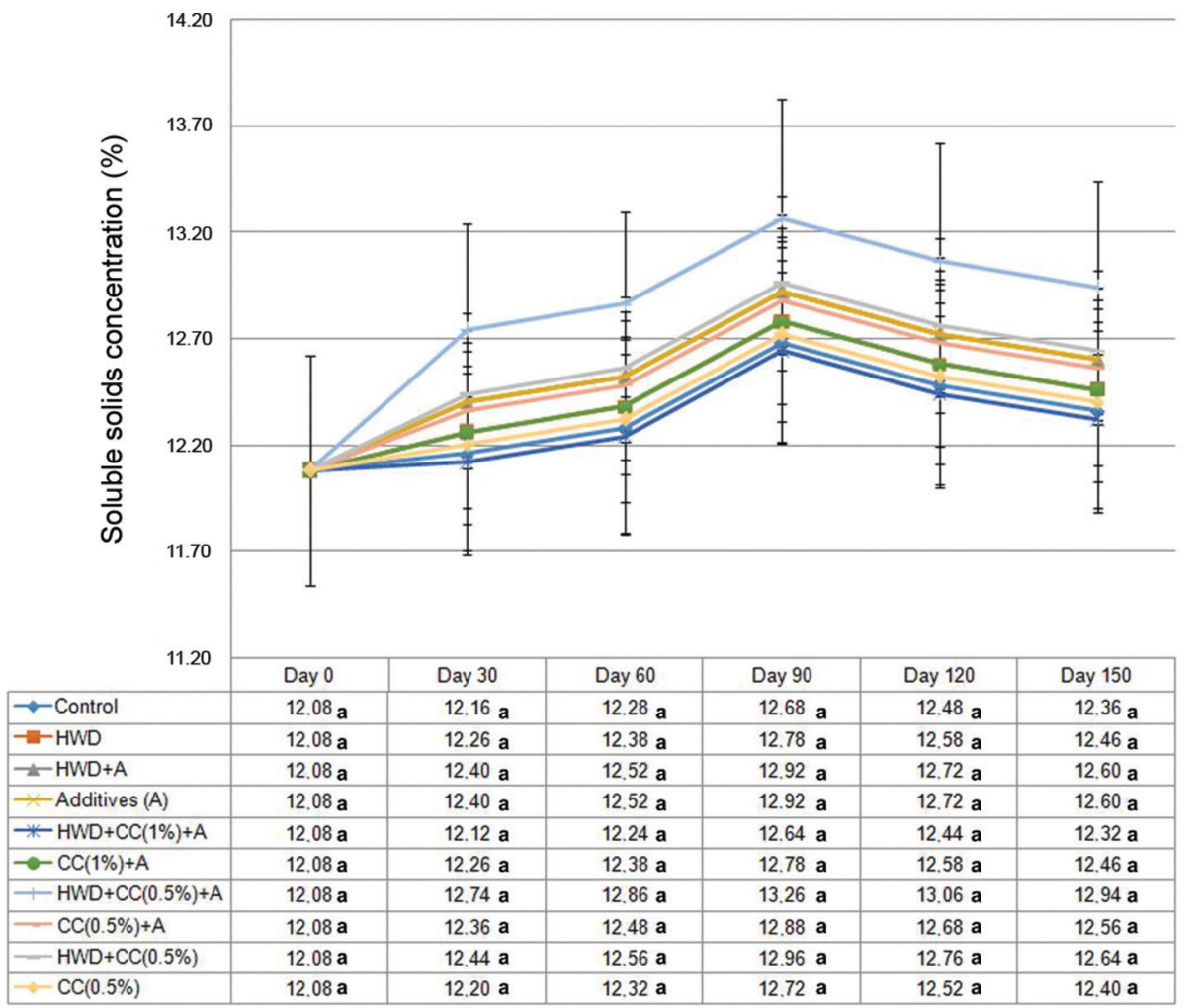

Figure 5. Effects of C. creticus leaf extracts, hot water dipping and their combination on the soluble solids concentration of Valencia oranges. Means of different treatments at the same storage time were compared with Tukey's HSD test $(p \leq 0.05)$ where means with the same letter or letters are statistically similar. 
the highest SSC was measured from the HWD + CC $(0.5 \%)+\mathrm{A}$ treatment with $12.94 \%$ and the lowest SCC was recorded from the similar treatment $(\mathrm{HWD}+\mathrm{CC}(1 \%)+\mathrm{A})$ as $12.32 \%$ (Figure 5). However, as described above, no significant difference was noted among the treatments.

\section{Influence of C. creticus leaf extracts and HWD on $\boldsymbol{T A}$}

The TA content of the Valencia oranges was found to have a decreasing trend during cold storage (Table 2 and Figure 6). The initial TA content was $2.75 \mathrm{~g} \cdot 100 \mathrm{~g}^{-1}$ and it decreased to $1.52 \mathrm{~g} \cdot 100 \mathrm{~g}^{-1}$ in 150 days of cold storage. The TA of oranges was observed to be significantly affected by the different treatments (Figure 6). This significant influence had begun to be observed after 90 days of cold storage. At that time, the highest TA content $\left(2.24 \mathrm{~g} \cdot 100 \mathrm{~g}^{-1}\right)$ was noted from HWD + CC $(0.5 \%)$ application and the lowest TA content $\left(1.84 \mathrm{~g} \cdot 100 \mathrm{~g}^{-1}\right)$ was observed from the control fruits. A similar trend was then continued till the end of the storage period. At the end of the 150 days of storage, the highest TA content was found to be $1.79 \mathrm{~g} \cdot 100 \mathrm{~g}^{-1}$ from the fruits treated with HWD + CC $(0.5 \%)$. Results suggest that both the HWD and C. creticus leaf extracts are effective in delaying the reduction of TA and their combination provides the best results. Moreover, the Additives alone treatment was found to have a slight effect on delaying the decrease in TA, but the highest efficacy was noted from the combination of HWD and C. creticus leaf extracts, without the Additives.

\section{Influence of C. creticus leaf extracts and HWD on $A s A$}

AsA is among the most important quality parameters of Valencia oranges. It is so important for consumers because of its confirmed health benefits and high antioxidant activity. The AsA values of Valencia oranges in the present study showed a similar trend with SSC during the cold storage period (Table 2). It was noted to have an increasing trend during the first 90 days of storage and then it decreased. However, the final AsA content of the Valencia oranges was recorded as higher than the initial value. On the other hand, findings of current work showed that all test applications, alone or in combination, have a significant influence on the AsA content. As seen from Figure 7, the lowest AsA content was measured from the control oranges and was followed

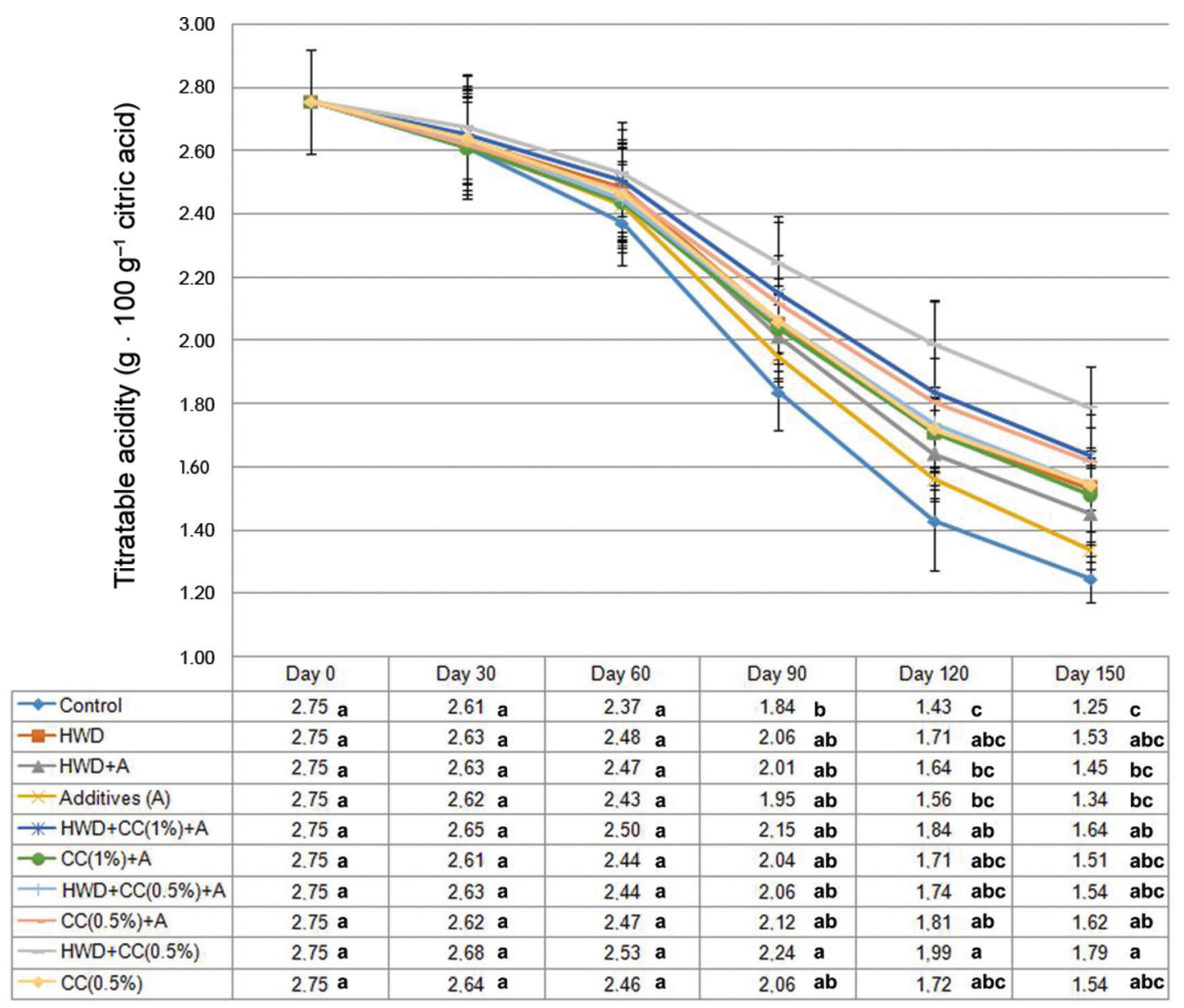

Figure 6. Effects of $C$. creticus leaf extracts, hot water dipping and their combination on the titratable acidity of Valencia oranges. Means of different treatments at the same storage time were compared with Tukey's HSD test $(p \leq 0.05)$ where means with the same letter or letters are statistically similar. 


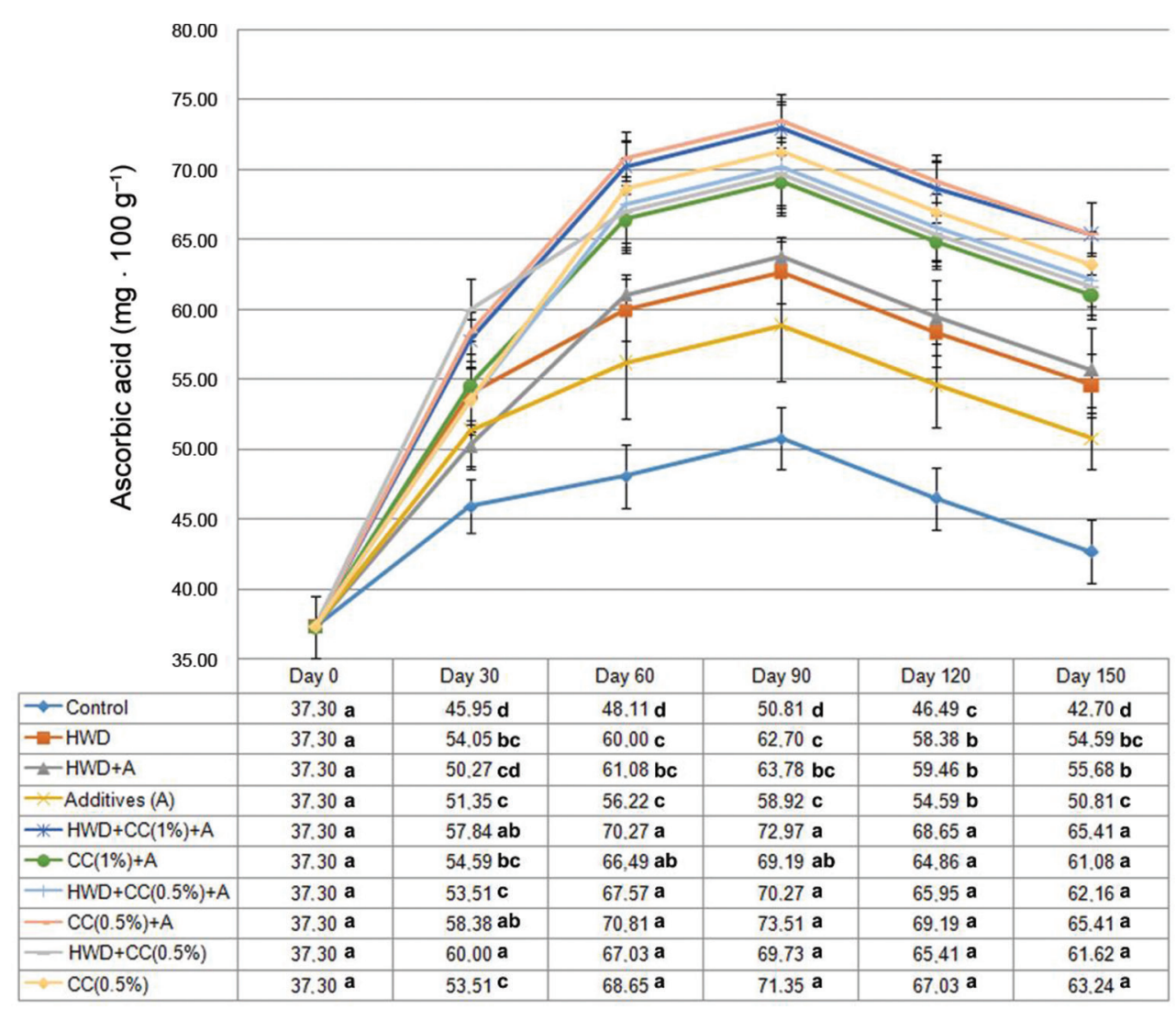

Figure 7. Effects of C. creticus leaf extracts, hot water dipping and their combination on the ascorbic acid of Valencia oranges. Means of different treatments at the same storage time were compared with Tukey's HSD test $(p \leq 0.05)$ where means with the same letter or letters are statistically similar.

by the oranges treated with Additives. This treatment was followed by HWD and HWD + A treatments. Results also suggested that there is no any significant difference among the other treatments. At the 150th day of cold storage, the highest AsA content was noted from the HWD + CC (1\%) + A and HWD + CC (0.5\%) + A treatments with the same value as $65.41 \mathrm{mg} \cdot 100 \mathrm{~g}^{-1}$.

\section{Influence of $C$. creticus leaf extracts and HWD on $R R$}

$\mathrm{RR}$ is an important parameter determining the storage duration and quality of fresh horticultural products. Cold storage, HWD and coatings, alone or in combination, are known to reduce the RR and improve the storability of products. The findings of current work showed that RR has a decreasing trend during the first 90 days of storage and then increased. This trend is different from that detected for SSC and AsA contents and is explaining the changes in SSC and TA. The RR was noted to be higher in the control groups, which clearly explains the quality loss in these untreated fruits (Figure 8). All of the test treatments were found to be efficient in reducing the $\mathrm{RR}$ as compared with the control treatment. The highest influence was noted from the HWD + CC $(0.5 \%)$, followed by the applications of CC $(0.5 \%)+\mathrm{A}$ and HWD $+\mathrm{CC}(1 \%)+\mathrm{A}$. All of these results suggest that the HWD is effective in reducing RR, but its efficacy is increasing with the Additives and/or C. creticus leaf extracts.

\section{DISCUSSIONS}

Results of current research suggested that the C. creticus leaf extract is effective in preserving the postharvest storability of Valencia oranges and a combination of this treatment with HWD provides the highest efficacy. The high efficacy of C. creticus leaf extract may be a result of its diverse and abundant chemical composition. Several previous studies have reported that the phytochemical composition of the plant extracts is responsible for their postharvest efficacy (Paolini et al., 2009; Abu-Orabi et al., 2020; Lahcen et al., 2020). Application of different biomaterials (edible coatings and films, essential oils, jasmonic acid, plant-derived products, etc.) has been previously recommended by several studies to preserve postharvest storability of fresh horticultural products (Chen et al., 2019; Kahramanoğlu 2019; Xin et al., 2019; Elkhetabi et al., 2020; Poveda, 2020; Riva et al., 2020). In most of those studies, the high efficacy of the plant extracts was correlated with the reduction in the RR of the products. In the present study, both the $C$. creticus leaf extract and HWD were found to reduce the $R R$ of the fresh Valencia oranges and help to preserve the postharvest storability of fresh oranges. 


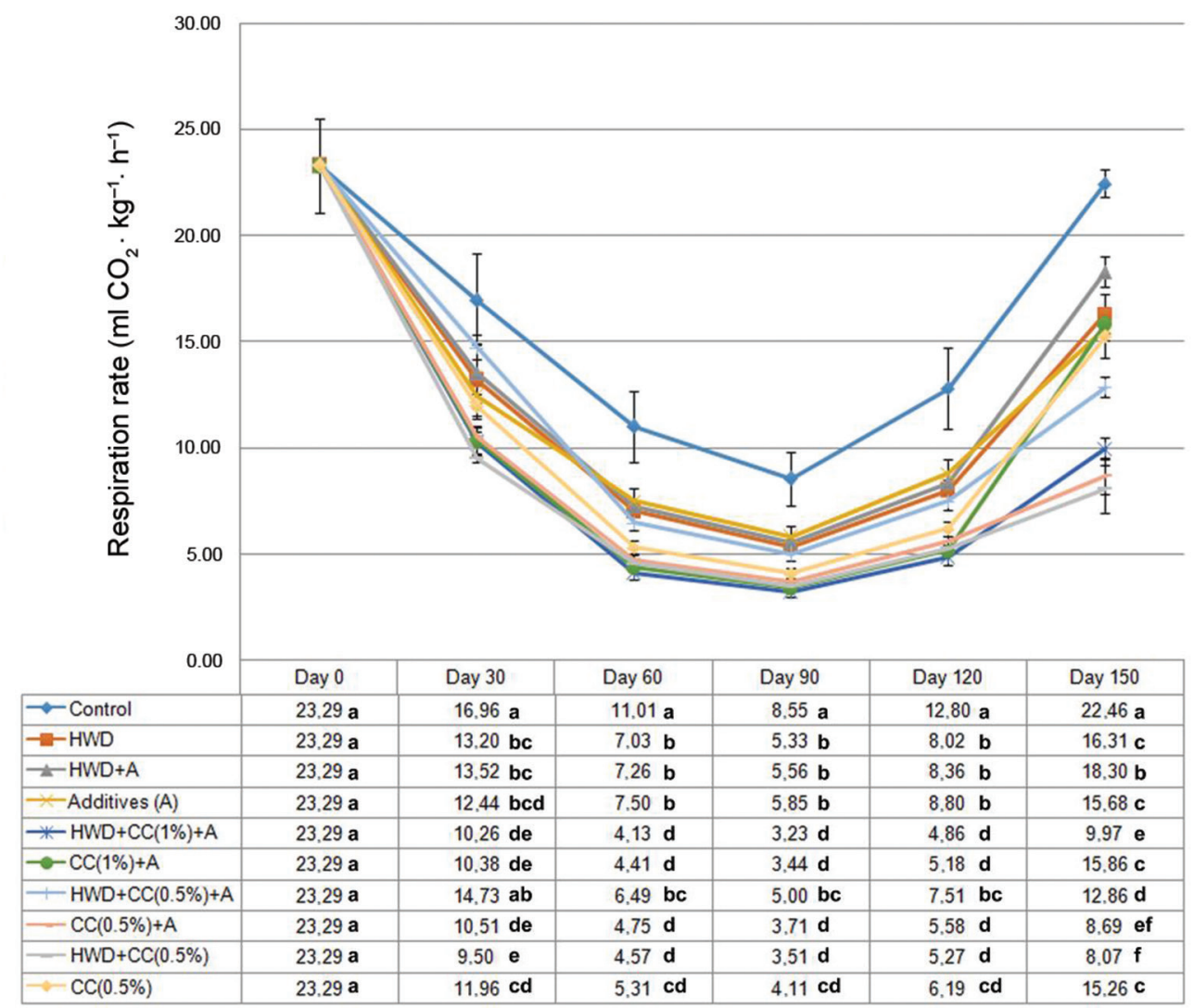

Figure 8. Effects of C. creticus leaf extracts, hot water dipping and their combination on the respiration rate of Valencia oranges. Means of different treatments at the same storage time were compared with Tukey's HSD test $(p \leq 0.05)$ where means with the same letter or letters are statistically similar.

Respiration determines the loss of sugars, promoting the deterioration of the fruit (Kahramanoğlu, 2017).

Summary of the results suggested that both C. creticus leaf extract and HWD, alone or in combination, are effective in reducing weight loss, preserving fruit firmness, maintaining visual quality, preventing DI, delaying the loss of TA and increasing AsA content. The results of the current study are found to be better than the findings of Rehman et al. (2018) who recommended 90 days of storage for the Valencia oranges with the application of methyl jasmonate. The higher efficacy of $C$. creticus leaf extract and HWD can be explained by their efficacy in reducing RR due to the modulation of gas exchange (Kator et al., 2018; Kahramanoğlu et al., 2019). The efficacy of HWD for reducing RR and weight loss of fruits is a well-known phenomenon, which was suggested by several studies (Yun et al., 2013; Opio et al., 2017; Atrash et al., 2018; Kahramanoğlu et al., 2020a; Wan et al., 2020). In a different study, Wei et al. (2018) noted that the efficacy of heat treatment for preserving the storability of strawberry fruits can be increased with the combination of heat treatment with tea tree oil. This report is in accordance with the findings of current work, where the efficacy of HWD was increased by its combination with C. creticus leaf extract.

Both the HWD and $C$. creticus leaf extract were found to maintain the visual quality of Valencia oranges in the present study. The postharvest application of biomaterials, which was previously recommended, provides favourable conditions for the horticultural products and helps to maintain their visual quality (Mohebbi et al., 2014; Sophia et al., 2015; Supapvanich et al., 2016). HWD and plant extracts can inhibit the polyphenol oxidase (PPO) and peroxidase (POD) enzymes in the fruit tissues and this helps to reduce chilling injury and browning (Sharma and Rao, 2015; Murmu and Mishra, 2017; Tahir et al., 2018). Similar to weight loss and visual quality, the results of the current research showed that the HWD and $C$. creticus leaf extract treatments are effective in preventing pathogenic decay. The efficacy of HWD was well known, which was reported by several studies (Yun et al., 2013; Opio et al., 2017; Atrash et al., 2018; Kahramanoğlu et al., 2020a; Wan et al., 2020). However, current results are novel for the $C$. creticus leaf extract. Kahramanoğlu et al. (2020b) suggested the mechanism for the control of postharvest pathogens by biomaterials. They are (i) improvement of fruits' resistance by the biosynthesis of some secondary metabolites and (ii) direct prevention of the spore and/or pathogen development with the inducement of ROS. Some other studies have also reported that the application of HWD, light and/or plant extracts may induce some pathogenesis-related proteins (PRs), which improve the products' tolerance (Hu et al., 2014; Wan et al., 2020). On the other hand, the results 
of the present study are in conjunction with the notes of Jemia et al. (2013) and Karim et al. (2017) who reported fungicidal activity for Cistus extracts.

Besides the above-discussed effects, both the C. creticus leaf extract and HWD were found to be effective for the prevention of changes in TA and AsA. TA, together with SSC, is the most important determinant of flavour, while the AsA is the most attractive characteristic of oranges by the consumers (Albertini et al., 2006). AsA is also an antioxidant and improves products' tolerance to oxidative stress and their storability. Previous studies have also suggested that the HWD treatment is effective for the prevention of changes in AsA contents (Imahori et al., 2016; Huan et al., 2017). The increase in AsA found in heat-treated fruits is probably due to the activation of the genes related to the AsA biosynthesis (Massot et al., 2013). Similarly to the present study, Erkan et al. (2005) reported that the HWD application helps to maintain the AsA content of mandarins.

\section{CONCLUSIONS}

The current research suggested that the application of HWD and C. creticus leaf extracts, alone or in combination, was effective in preserving orange weight during storage, preventing pathogenic decay, maintaining visual quality, keeping fruit firmness, delaying the reduction in TA, increasing ascorbic acid content and reducing RR of the orange fruits. The highest efficacy was obtained from the combination of these two treatments, and the postharvest storability of Valencia oranges was found to be increased up to 150 days at $6.0 \pm 1.0^{\circ} \mathrm{C}$ and $90-95 \% \mathrm{RH}$. The weight loss of the HWD + CC (0.5\%)-treated Valencia oranges was found to be $9.91 \%$ in 150 days of storage, which was noted as $16.83 \%$ for the untreated control fruits. The visual quality of these fruits has obtained a score of 3.20 in 150 days of storage, which is acceptable for marketability.

\section{FUNDING}

This research received no specific grant from any funding agency in the public, commercial, or not-for-profit sectors.

\section{AUTHOR CONTRIBUTIONS}

All authors decided and conceptualised the experiments. İ.K., S.U. and T.A. collected the materials, designed the experiments and collected the data. I.K., V.O. and C.W. performed the statistical analysis. I.K. and C.W. wrote the initial draft of the paper. All authors edited the paper and give the final approval.

\section{CONFLICT OF INTEREST}

The authors declare no conflict of interest.

\section{REFERENCES}

Abu-Orabi, S. T., Al-Qudah, M. A., Saleh, N. R., Bataineh, T. T., Obeidat, S. M., Al-Sheraideh, M. S., Al-Jaber, H. I., Tashtoush, H. I., And Lahham, J. N. (2020). Antioxidant activity of crude extracts and essential oils from flower buds and leaves of Cistus creticus and Cistus salviifolius. Arabian Journal of Chemistry, 13(7), 6256-6266.

Albertini, M. V., Carcouet, E., Pailly, O., Gambotti, C., Luro, F., AND Berti, L. (2006). Changes in organic acids and sugars during early stages of development of acidic and acidless citrus fruit. Journal of Agricultural and Food Chemistry, 54(21), 8335-8339.

Alhassan, N., Bowyer, M. C., Wills, R. B. H., Golding, J. B., And Pristijono, P. (2020). Postharvest dipping with 3,5,6-trichloro-2-pyridiloxyacetic acid solutions delays calyx senescence and loss of other postharvest quality factors of 'Afourer' mandarins, Navel and Valencia oranges. Scientia Horticulturae, 272, 109572, doi: 10.1016/j.scienta.2020.109572.

Altay, V. (2019). Ecology of Pinus sylvestris L. forests A case study from Ýstanbul (Turkey). Pakistan Journal of Botany, 51(5), 1711-1718.

Atrash, S., Ramezanian, A., Rahemi, M., Ghalamfarsa, R. M., And Yahia, E. (2018). Antifungal effects of savory essential oil, gum Arabic, and hot water in Mexican lime fruits. HortScience, 53(4), 524-530.

CAO, S., ZHeng, Y., AND YANG, Z. (2011). Effect of 1-MCP treatment on nutritive and functional properties of loquat fruit during cold storage. New Zealand Journal of Crop and Horticultural Science, 39(1), 61-70.

Chen, J., Shen, Y., Chen, C., and Wan, C. (2019). Inhibition of key citrus postharvest fungal strains by plant extracts in vitro and in vivo: A review. Plants, 8(2), 26, doi: 10.3390/plants8020026.

ÇolaK, A. M., And ÖzoĞUl, A. (2020). Pomological and biochemical characteristics of local apple genotypes grown in Uşak-Turkey. Pakistan Journal of Botany, 52(3), 955-961.

Dimas, K., Demetzos, C., Mitaku, S., Vaos, B., Marselos, M., Tzavaras, T., and Kokkinopoulos, D. (1999). Cytotoxic activity and antiproliferative effects of a new semi-synthetic derivative of Ent-3 beta-hydroxy-13-epi-manoyl oxide on human leukemic cell lines. Anticancer Research, 19(5B), 4065-4072.

Elkhetabi, A., Lahlali, R., Askarne, L., Ezrari, S., El Ghadaroui, L., Tahiri, A., Hrustic, J., and Amiri, S. (2020). Efficacy assessment of pomegranate peel aqueous extract for brown rot (Monilinia spp.) disease control. Physiological and Molecular Plant Pathology, 110, 101482, doi: 10.1016/j. pmpp.2020.101482.

Erkan, M., Pekmezci, M., Karasahin, I., and Uslu, H. (2005). Reducing chilling injury and decay in stored 
'Clementine' mandarins with hot water and curing treatments. European Journal of Horticultural Science, 70(4), 183.

FAO. (2020). Retrieved from http://www.fao.org/faostat/ en/\#data/QC.

Farag, M. A., Abib, B., Ayad, L., And Khattab, A. R. (2020). Sweet and bitter oranges: An updated comparative review of their bioactives, nutrition, food quality, therapeutic merits and biowaste valorization practices. Food Chemistry, 331, 127306, doi: 10.1016/j.foodchem.2020.127306.

FilipiaK, M., AND Weiner, J. (2017). Plant-insect interactions: the role of ecological stoichiometry. Acta Agrobotanica, 70(1), 1710, doi: 10.5586/aa.1710.

Fonseca, S. C., Oliveira, F. A., and Brecht, J. K. (2002). Modelling respiration rate of fresh fruits and vegetables for modified atmosphere packages: A review. Journal of Food Engineering, 52(2), 99-119.

Hassanein, R. A., Salem, E. A., and Zahran, A. A. (2018). Efficacy of coupling gamma irradiation with calcium chloride and lemongrass oil in maintaining guava fruit quality and inhibiting fungal growth during cold storage. Folia Horticulturae, 30(1), 67-78.

Huan, C., Han, S., Jiang, L., An, X., Yu, M., Xu, Y., AND Yu, Z. (2017). Postharvest hot air and hot water treatments affect the antioxidant system in peach fruit during refrigerated storage. Postharvest Biology and Technology, 126, 1-14.

Hu, M., Yang, D., Huber, D. J., Jiang, Y., Li, M., GaO, Z., AND ZHANG, Z. (2014). Reduction of postharvest anthracnose and enhancement of disease resistance in ripening mango fruit by nitric oxide treatment. Postharvest Biology and Technology, 97, 115-122.

Hussien, A., Ahmed, Y., Al-Essawy, A. H., And Youssef, K. (2018). Evaluation of different salt-amended electrolysed water to control postharvest moulds of citrus. Tropical Plant Pathology, 43(1), 10-20.

IMAHORI, Y., BAI, J., AND BALDWIN, E. (2016). Antioxidative responses of ripe tomato fruit to postharvest chilling and heating treatments. Scientia Horticulturae, 198, 398-406.

Jemia, M. B., Kchouk, M. E., Senatore, F., Autore, G., Marzocco, S., De Feo, V., and Bruno, M. (2013). Antiproliferative activity of hexane extract from Tunisian Cistus libanotis, Cistus monspeliensis and Cistus villosus. Chemistry Central Journal, 7(1), 47-53.

KahramanoĞLu, I. (2017). Introductory chapter: Postharvest physiology and technology of horticultural crops. In I. Kahramanoglu (Ed.), Postharvest handling, (pp. 1-5), London, UK: IntechOpen.

KahramanoĞLU, I. (2019). Effects of lemongrass oil application and modified atmosphere packaging on the postharvest life and quality of strawberry fruits. Scientia Horticulturae, 256, 108527, doi: 10.1016/j. scienta.2019.05.054.

Kahramanoŭlu, I., Chen, C., Chen, J., and Wan, C. (2019). Chemical constituents, antimicrobial activity, and food preservative characteristics of Aloe vera gel. Agronomy, 9(12), 831, doi: 10.3390/ agronomy9120831.

KahramanoĞlu, I., Chen, C., Chen, Y., Chen, J., Gan, Z., AND WAN, C. (2020a). Improving storability of "Nanfeng" mandarins by treating with postharvest hot water dipping. Journal of Food Quality, 2020, 8524952, doi: 10.1155/2020/8524952.

KahramanoĞlu, I., Nisar, M. F., Chen, C., Usanmaz, S., Chen, J., AND WAN, C. (2020b). Light: An alternative method for physical control of postharvest rotting caused by fungi of citrus fruit. Journal of Food Quality, 2020, 8821346, doi: 10.1155/2020/8821346.

Karim, H., Boubaker, H., Askarne, L., Cherifi, K., Lakhtar, H., Msanda, F., and Aoumar, A. A. B. (2017). Use of Cistus aqueous extracts as botanical fungicides in the control of Citrus sour rot. Microbial Pathogenesis, 104, 263-267.

Kator, L., Hosea, Z. Y., and Ene, O. P. (2018). The efficacy of Aloe vera coating on postharvest shelf life and quality tomato fruits during storage. Asian Research Journal of Agriculture, 8(4), 1-9.

Kharchoufi, S., Parafati, L., Licciardello, F., Muratore, G., Hamdi, M., Cirvilleri, G., And Restuccia, C. (2018). Edible coatings incorporating pomegranate peel extract and biocontrol yeast to reduce Penicillium digitatum postharvest decay of oranges. Food Microbiology, 74, 107-112.

Косн, S., Epp, A., Lohmann, M., And BöL, G. F. (2017). Pesticide residues in food: attitudes, beliefs, and misconceptions among conventional and organic consumers. Journal of Food Protection, 80(12), 2083-2089.

Lado, J., Rodrigo, M. J., López-Climent, M., GómezCADENAS, A., AND ZACARÍAs, L. (2016). Implication of the antioxidant system in chilling injury tolerance in the red peel of grapefruit. Postharvest Biology and Technology, 111, 214-223.

Lahcen, S. A., El Hattabi, L., Benkaddour, R., Chahboun, N., Ghanmi, M., Satrani, B., And Zarrouk, A. (2020). Chemical composition, antioxidant, antimicrobial and antifungal activity of Moroccan Cistus creticus leaves. Chemical Data Collections, 26, 100346, doi: 10.1016/j. cdc.2020.100346.

Massot, C., Bancel, D., Lauri, F. L., Truffault, V., Baldet, P., Stevens, R., and Gautier, H. (2013). High temperature inhibits ascorbate recycling and light stimulation of the ascorbate pool in tomato despite increased expression of biosynthesis genes. PLoS ONE, 8(12), e84474, doi: 10.1371/journal. pone. 0084474 .

Mohebbi, M., Hasanpour, N., Ansarifar, E., And Amiryousefi, M. R. (2014). Physicochemical properties of bell pepper and kinetics of its color change influenced by Aloe vera and gum tragacanth coatings during storage at different temperatures. Journal of Food Processing and Preservation, 38(2), 684-693. 
Moosa, A., SAhi, S. T., Khan, S. A., and Malik, A. U. (2019). Salicylic acid and jasmonic acid can suppress green and blue moulds of citrus fruit and induce the activity of polyphenol oxidase and peroxidase. Folia Horticulturae, 31(1), 195-204.

Moraes Bazioli, J., Belinato, J. R., Costa, J. H., Akiyama, D. Y., Pontes, J. G. D. M., And Kupper, K. C., AND FILL, T. P. (2019). Biological control of citrus postharvest phytopathogens. Toxins, 11(8), 460, doi: 10.3390/toxins11080460.

Morales-Soto, A., Oruna-Concha, M. J., Elmore, J. S., Barrajón-Catalán, E., Micol, V., Roldán, C., and Segura-Carretero, A. (2015). Volatile profile of Spanish Cistus plants as sources of antimicrobials for industrial applications. Industrial Crops and Products, 74, 425-433.

Murmu, S. B., And Mishra, H. N. (2017). Optimization of the Arabic gum based edible coating formulations with sodium caseinate and tulsi extract for guava. LWT, 80, 271-279.

Ncama, K., Mditshwa, A., Tesfay, S. Z., Mbili, N. C., And MagwaZA, L. S. (2019). Topical procedures adopted in testing and application of plant-based extracts as bio-fungicides in controlling postharvest decay of fresh produce. Crop Protection, 115, 142-151.

Okatan, V., ÇolaK, A. M., Güçlü, S. F., and GündoĞdu, M. (2018). The comparison of antioxidant compounds and mineral content in some pomegranate (Punica granatum L.) genotypes grown in the east of turkey. Acta Scientiarum Polonorum, Hortorum Cultus, 17(4), 201-211.

Oller-López, J. L., Rodríguez, R., Cuerva, J. M., Oltra, J. E., Bazdi, B., Dahdouh, A., And Mansour, A. I. (2005). Composition of the essential oils of Cistus ladaniferus and C. monspeliensis from Morocco. Journal of Essential Oil Research, 17(5), 553-555.

Opio, P., Jitareerat, P., Pongrrasert, N., Wongs-Aree, C., Suzuki, Y., and SRilaong, V. (2017). Efficacy of hot water immersion on lime (Citrus auranifolia Swingle cv. Paan) fruit packed with ethanol vapor in delaying chlorophyll catabolism. Scientia Horticulturae, 224, 258-264.

Palou, L., Valencia-Chamorro, S. A., and Pérez-Gago, M. B. (2015). Antifungal edible coatings for fresh citrus fruit: A review. Coatings, 5(4), 962-986.

Paolini, J., Falchi, A., Quilichini, Y., Desjobert, J. M., De Cian, M. C., Varesi, L., and Costa, J. (2009). Morphological, chemical and genetic differentiation of two subspecies of Cistus creticus L. (C. creticus subsp. eriocephalus and C. creticus subsp. corsicus). Phytochemistry, 70(9), 1146-1160.

Pinto, L., Cefola, M., Bonifacio, M. A., Cometa, S., Bocchino, C., Pace, B., De Giglio, E., Palumbo, M., Sada, A., Logrieco, A. F., And Baruzzi, F. (2021). Effect of red thyme oil (Thymus vulgaris L.) vapours on fungal decay, quality parameters and shelf life of oranges during cold storage.
Food Chemistry, 336C, 127590, doi: 10.1016/j. foodchem.2020.127590.

PovedA, J. (2020). Use of plant-defense hormones against pathogen-diseases of postharvest fresh produce. Physiological and Molecular Plant Pathology, 111, 101521, doi: 10.1016/j.pmpp.2020.101521.

Rehman, M., Singh, Z., And Khurshid, T. (2018). Methyl jasmonate alleviates chilling injury and regulates fruit quality in 'Midknight' Valencia orange. Postharvest Biology and Technology, 141, $58-62$.

Riva, S. C., Opara, U. O., and Fawole, O. A. (2020). Recent developments on postharvest application of edible coatings on stone fruit: A review. Scientia Horticulturae, 262, 109074, doi: 10.1016/j. scienta.2019.109074.

Sharma, R. R., Singh, D., And Singh, R. (2009). Biological control of postharvest diseases of fruits and vegetables by microbial antagonists: A review. Biological Control, 50(3), 205-221.

Sharma, S., and RaO, T. V. R. (2015). Xanthan gum based edible coating enriched with cinnamic acid prevents browning and extends the shelf-life of freshcut pears. LWT-Food Science and Technology, 62(1 Part 2), 791-800.

Silva, I. M. B. R., Rocha, R. H. C., De Souza Silva, H., Dos Santos Moreira, I., De Sousa, F. D. A., and DE PAIVA, E. P. (2015). Quality and post-harvest life organic pomegranate 'Molar' produced in Paraiba semiarid. Semina: Ciências Agrárias, 36(4), 2555-2564.

Silvestre, C., Duraccio, D., and Cimmino, S. (2011). Food packaging based on polymer nanomaterials. Progress in Polymer Science, 36(12), 1766-1782.

Sophia, O., Robert, G. M., And Ngwela, W. J. (2015). Effect of Aloe vera gel coating on postharvest quality and shelf life of mango (Mangifera indica L.) fruits var. Ngowe. Journal of Horticulture and Forestry, 7(1), 1-7.

Supapvanich, S., Mitrsang, P., Srinorkham, P., Boonyaritthongchai, P., And Wongs-Aree, C. (2016). Effects of fresh Aloe vera gel coating on browning alleviation of fresh cut wax apple (Syzygium samarangenese) fruit cv. Taaptimjaan. Journal of Food Science and Technology, 53(6), 2844-2850.

Tahir, H. E., Xiaobo, Z., Jiyong, S., Mahunu, G. K., Zhai, X., And Mariod, A. A. (2018). Quality and postharvest-shelf life of cold-stored strawberry fruit as affected by gum Arabic (Acacia senegal) edible coating. Journal of Food Biochemistry, 42(3), e12527, doi: 10.1111/jfbc.12527.

Tayel, A. A., Moussa, S. H., Salem, M. F., Mazrou, K. E., AND El-Tras, W. F. (2016). Control of citrus molds using bioactive coatings incorporated with fungal chitosan/plant extracts composite. Journal of the Science of Food and Agriculture, 96, 1306-1312. 
Tomazoni,E.Z.,Pansera, M.R.,Pauletti, G.F., Moura, S., Ribeiro, R. T., AND Schwambach, J. (2016). In vitro antifungal activity of four chemotypes of Lippia alba (Verbenaceae) essential oils against Alternaria solani (Pleosporeaceae) isolates. Anais da Academia Brasileira de Ciências, 88(2), 999-1010.

Troyo, R. D., ANd Acedo, A. L. (2019). Effects of calcium ascorbate and calcium lactate on quality of fresh-cut pineapple (Ananas comosus). International Journal of Agriculture Forestry and Life Sciences, 3(1), 143-150.

Wan, C., KahramanoĐlu, I., Chen, J., Gan, Z., And Chen, C. (2020). Effects of hot air treatments on postharvest storage of Newhall navel orange. Plants, 9(2), 170, doi: 10.3390/plants9020170.

Wei, Y., Wei, Y., Xu, F., And Shao, X. (2018). The combined effects of tea tree oil and hot air treatment on the quality and sensory characteristics and decay of strawberry. Postharvest Biology and Technology, 136, 139-144.

Whitney, E., And Rolfes, S. (1999). Understanding nutrition. Belmont, CA: Wadsworth Publishing Company.

Wu, Y., Ouyang, Q., and Tao, N. (2016). Plasma membrane damage contributes to antifungal activity of citronellal against Penicillium digitatum.
Journal of Food Science and Technology, 53, 3853-3858.

Xin, Z., Ouyang, Q., Wan, C., Che, J., Li, L., Chen, J., AND TAO, N. (2019). Isolation of antofine from $C y$ nanchum atratum BUNGE (Asclepiadaceae) and its antifungal activity against Penicillium digitatum. Postharvest Biology and Technology, 157, 110961, doi: 10.1016/j.postharvbio.2019.110961.

Youssef, K., AND Hussien, A. (2020). Electrolysed water and salt solutions can reduce green and blue molds while maintain the quality properties of 'Valencia' late oranges. Postharvest Biology and Technology, 159, 111025, doi: 10.1016/j.postharvbio.2019.111025.

Yun,Z., GaO, H., Liu, P., Liu, S., Luo, T., Jin, S., AndDeng, X. (2013). Comparative proteomic and metabolomic profiling of citrus fruit with enhancement of disease resistance by postharvest heat treatment. BMC Plant Biology, 13(1), 44, doi: 10.1186/1471-2229-13-44.

Zudaire, L., Viñas, I., Lafarga, T., Plaza, L., Echeverria, G., Bobo, G., Altisent, R., And Aguiló-Aguayo, I. (2019). Effect of calcium salts and antioxidant treatment on the storage quality of fresh-cut Conference pears. International Journal of Agriculture, Forestry and Life Sciences, 3(2), 331-344.

Received: July 29, 2020; accepted: October 20, 2020. 